Brit. J. industr. Med., 1961, 18, 58.

\title{
COPROPORPHYRINURIA IN GROUPS OF WORKERS AS AN INDEX OF INORGANIC LEAD ABSORPTION
}

\author{
BY \\ R. L. ZIELHUIS \\ From the Department of Occupational Medicine, Netherlands Institute for Preventive Medicine, Leyden
}

(RECEIVED FOR PUBLICATION AUGUST 9, 1960)

In a study of signs and symptoms of lead intoxication in workers in lead processing industries in the Netherlands, use has been made of the apparatus described by Donath (1956) for semiquantitative determination of coproporphyrin excretion. The significance of this method in the screening of exposed groups of workers has been investigated. The method proved to be a valuable tool in the prevention of inorganic lead intoxication. The frequency distribution of coproporphyrinuria in groups of workers indicates the extent of lead exposure. If the average coproporphyrinuria exceeds 1.5 degrees on the Donath scale there is an increased lead intake. From the frequency distribution of coproporphyrinuria the degree of air pollution with lead and the degree of anaemia due to lead intake may be roughly estimated.

Although the symptomatic occurrence of increased coproporphyrin excretion was established before the beginning of this century, it was a long time before determination of coproporphyrin excretion became a routine screening procedure in the prevention of industrial lead intoxication. Since Vannotti (1937) numerous authors have been of the opinion that coproporphyrinuria is a constant early sign of increased inorganic lead intake. Goldblatt and Goldblatt (1956), for instance, state that a workman does not suffer from lead intoxication if the coproporphyrin excretion consistently stays within normal limits. A normal coproporphyrinuria is therefore of great significance in evaluating lead exposure.

Increased coproporphyrinuria is a sensitive sign of lead absorption. It occurs very early, before basophilic punctated erythrocytes appear or the haemoglobin decreases. A close correlation with clinical symptoms cannot be established in individuals, presumably because of the extreme sensitivity: a subjectively latent lead intoxication causes an increased coproporphyrinuria long before the haemoglobin value decreases. In groups, however, Pinto, Einert, Roberts, Winn, and Nelson (1952) found a correlation between the occurrence of subjective symptoms and coproporphyrinuria $(>400 \gamma /$ l.). The same is true for the correlation between urinary excretion of lead and coproporphyrin (Waldman and Seideman, 1950; Johnson and Whitman, 1950; Harrold, Meek, and Padden, 1952; Gupta and Iyer, 1954). It may even be true that an increase in coproporphyrin excretion occurs earlier than an increase in lead excretion, as observed by the present author in animal experiments (Zielhuis, 1959a).

Normal values in non-exposed persons have been established by several authors, most of whom accept $200 \mathrm{\gamma} / \mathrm{l}$. as the upper limit of normal. Few of these authors, however, suggested "danger-levels" to be used as criteria in the prevention of lead intoxication. Those which are mentioned differ greatly.

\section{Method}

One of the difficulties which had to be overcome before determination of coproporphyrin excretion could constitute a routine screening procedure was the need for a less elaborate method of quantitative determination in urine. Only after Hijmans van den Bergh and Grotepass (1933) evolved their semi-quantitative method (estimation of the degree of fluorescence in ultra-violet light after extraction in ether-glacial acetic acid) could the use of increased coproporphyrinuria in the practice of industrial hygiene be accepted. Several semiquantitative methods came into use which were based on Hijmans van den Bergh's method, but in more or less modified form (Wyllie, 1955). In most cases, however, subjective estimation of the degree of fluorescence (e.g. $0,+,++,+++$, and so on) made comparison of results an inaccurate procedure. In the Netherlands Institute for Preventive Medicine at Leyden, Donath (1956) constructed an apparatus which made objective 
TABLE 1

COPROPORPHYRINURIA ESTIMATIONS (DONATH SCALE) IN RELATION TO LEAD-IN-AIR CONCENTRATIONS AND DURATION OF EXPOSURE IN 157 WORKERS FROM LEAD PIGMENT FACTORIES A AND B

\begin{tabular}{|c|c|c|c|c|c|c|c|c|c|c|c|c|c|c|c|}
\hline \multirow{3}{*}{$\begin{array}{c}\text { Lead-in-Air } \\
\text { \&oncentrations } \\
\left(\mathrm{mg} . \mathrm{Pb} / \mathrm{m}^{3}\right)\end{array}$} & & \multicolumn{12}{|c|}{ Duration of Exposure } & \multirow{2}{*}{\multicolumn{2}{|c|}{$\begin{array}{l}\text { Total Workers } \\
\text { Median } \\
\text { Coproporphyrinuria } \\
\text { and (range) }\end{array}$}} \\
\hline & & \multicolumn{2}{|c|}{$\begin{array}{c}0-6 \\
\text { months }\end{array}$} & \multicolumn{2}{|c|}{$\begin{array}{c}7-12 \\
\text { months }\end{array}$} & \multicolumn{2}{|c|}{$\begin{array}{c}1-5 \\
\text { years }\end{array}$} & \multicolumn{2}{|c|}{$\begin{array}{c}6-10 \\
\text { years }\end{array}$} & \multicolumn{2}{|c|}{$\begin{array}{l}11-20 \\
\text { years }\end{array}$} & \multicolumn{2}{|c|}{$\begin{array}{r}>20 \\
\text { years }\end{array}$} & & \\
\hline & & $\mathbf{A}$ & B & $\mathbf{A}$ & $\mathbf{B}$ & $\mathbf{A}$ & $\mathbf{B}$ & $\mathbf{A}$ & $\mathbf{B}$ & $\mathbf{A}$ & $\mathbf{B}$ & $\mathbf{A}$ & $\mathbf{B}$ & $\mathbf{A}^{*}$ & B \\
\hline 0.05 & Number of workers $<_{\text {(range) }}^{\text {mean }}$ & $\begin{array}{c}2 \\
1 \cdot 0 \\
(1-1)\end{array}$ & $\begin{array}{c}4 \\
1 \cdot 2 \\
(1-2)\end{array}$ & - & $\begin{array}{c}2 \\
2 \cdot 5 \\
(2-3)\end{array}$ & - & $\begin{array}{c}2 \\
1 \cdot 5 \\
(1-2)\end{array}$ & $\begin{array}{c}2 \\
1 \cdot 5 \\
(1-2)\end{array}$ & - & $\begin{array}{l}1 \\
1 \\
(-)\end{array}$ & $\begin{array}{l}1 \\
1 \\
(-)\end{array}$ & - & $\begin{array}{c}6 \\
1 \cdot 3 \\
(1-2)\end{array}$ & $\begin{array}{c}5 \\
1 \\
(1-2)\end{array}$ & $\begin{array}{c}15 \\
1 \\
(1-3)\end{array}$ \\
\hline $0 \cdot 05-0 \cdot 15$ & Number of workers $<_{\text {(range) }}^{\text {mean }}$ & $\begin{array}{c}7 \\
3 \cdot 1 \\
(1-4)\end{array}$ & $\begin{array}{r}4 \\
2 \cdot 0 \\
(1-3)\end{array}$ & $\begin{array}{c}5 \\
2 \cdot 4 \\
(1-4)\end{array}$ & $\begin{array}{c}8 \\
2.9 \\
(1-5)\end{array}$ & $\begin{array}{c}15 \\
3 \cdot 6 \\
(3-6)\end{array}$ & $\begin{array}{c}11 \\
2 \cdot 2 \\
(1-4)\end{array}$ & $\begin{array}{c}11 \\
3 \cdot 2 \\
(1-7)\end{array}$ & $\begin{array}{c}8 \\
2 \cdot 1 \\
(1-3)\end{array}$ & $\begin{array}{r}4 \\
3 \cdot 5 \\
(1-5)\end{array}$ & $\begin{array}{r}10 \\
3 \cdot 3 \\
(1-5)\end{array}$ & $\begin{array}{r}5 \\
3 \cdot 2 \\
(2-4)\end{array}$ & $\begin{array}{c}10 \\
2 \cdot 3 \\
(1-4)\end{array}$ & $\begin{array}{r}47 \\
3 \\
(1-7)\end{array}$ & $\begin{array}{r}51 \\
2 \\
(1-5)\end{array}$ \\
\hline $0.15-0.65$ & Number of workers $<_{\text {(range) }}^{\text {mean }}$ & - & $\begin{array}{l}1 \\
5 \\
(-)\end{array}$ & $\begin{array}{c}3 \\
5 \cdot 0 \\
(3-7)\end{array}$ & $\begin{array}{r}4 \\
5 \cdot 0 \\
(3-6)\end{array}$ & $\begin{array}{r}6 \\
5 \cdot 5 \\
(5-6)\end{array}$ & $\begin{array}{r}2 \\
4 \cdot 5 \\
(3-6)\end{array}$ & $\begin{array}{r}7 \\
4 \cdot 0 \\
(2-7)\end{array}$ & $\begin{array}{l}1 \\
2 \\
(-)\end{array}$ & - & $\begin{array}{c}2 \\
4 \cdot 5 \\
(4-5)\end{array}$ & $\begin{array}{r}3 \\
4 \cdot 3 \\
(3-6)\end{array}$ & $\begin{array}{l}1 \\
6 \\
(-)\end{array}$ & $\begin{array}{c}19 \\
5 \\
(2-7)\end{array}$ & $\begin{array}{c}11 \\
5 \\
(2-6)\end{array}$ \\
\hline$=0.65$ & Number of workers $<_{\text {(range) }}^{\text {mean }}$ & $\begin{array}{l}- \\
-\end{array}$ & - & $\begin{array}{c}2 \\
6 \cdot 0 \\
(6-6)\end{array}$ & $\begin{array}{c}2 \\
5 \cdot 5 \\
(5-6)\end{array}$ & $\begin{array}{r}2 \\
5 \cdot 0 \\
(4-6)\end{array}$ & $\begin{array}{l}- \\
-\end{array}$ & $\begin{array}{l}1 \\
5 \\
(-)\end{array}$ & $\begin{array}{l}- \\
-\end{array}$ & $\begin{array}{r}1 \\
5 \\
(-)\end{array}$ & $\begin{array}{l}1 \\
5 \\
(-)\end{array}$ & $\begin{array}{l}- \\
-\end{array}$ & - & $\begin{array}{r}6 \\
5 \cdot 5 \\
(4-6)\end{array}$ & $\begin{array}{c}3 \\
5 \\
(5-6)\end{array}$ \\
\hline
\end{tabular}

* Owing to frequent transfer it was not possible to make reasonable estimates of the exposure of four of the 81 workers in Factory A.

semi-quantitative determination possible. In this method $10 \mathrm{ml}$. of recently voided urine are shaken in a test-tube with $2 \mathrm{ml}$. ether-glacial acetic acid and the fluorescence of the foamy ether layer in ultra-violet light is compared with the fluorescence of eight specially prepared small circular pieces of paper mounted on a rotating disc. The intensity of fluorescence on this scale corresponds with the following logarithmically increasing coproporphyrin concentrations: degree 1: 0-50 $/ 1 ., 2: 50-100 \gamma / 1$, 3: $100-200 \gamma / 1 ., 4: 200-400 \gamma / 1 ., 5: 400-800 \gamma / 1 ., 6: 800-$ $1600 \gamma / 1 ., 7: 1600-3000 \gamma / 1$. and 8: 3000-5000y/l. With a minimum of instruction this apparatus can be used to determine the degree of coproporphyrinuria easily and quickly on the factory premises; it yields reliably reproducible results with a negligible variability due to observer error (Donath, 1955). The urine of at least 30 persons can be examined in half an hour.

\section{The Present Investigation}

In 112 males not exposed to lead, most of them industrial workers, approximately $70 \%$ showed a coproporphyrinuria degree 1 on the Donath scale $(0-50 \gamma / 1),. 20 \%$ degree $2(50-100 \gamma / 1$.$) , and 10 \%$ degree $3(100-200 \gamma / 1$.$) . This frequency distribution$ was presumed to be "normal" and was also consistent with the data in the literature. The "normal" average of this group $\left(\frac{\sum \text { coprop. }}{n}\right)$ was 1.4 degrees.

In several investigations in many lead processing factories a total of 513 workers with a varied exposure to lead were examined. In two factories
(A and B), each producing lead pigments (mainly lead chromate, lead sulphate, and lead stearate) in 1957 and 1958, lead-in-air concentrations were determined by the section for Industrial Hygiene of the Central Netherlands Organization for Applied Research (T.N.O.) and in the same period the workers (81 in factory $\mathrm{A}, 80$ in factory $\mathrm{B}$ ) were examined by the author. Table 1 gives coproporphyrinuria estimations on the Donath scale, related to intensity and duration of exposure.

From this Table it can be seen that workers $(n=20)$ exposed to less than $0.05 \mathrm{mg} . \mathrm{Pb} / \mathrm{m}^{3}$ never had a coproporphyrinuria $>3$ on the Donath scale $(100-200 \gamma / 1$.$) ; with increasing lead-in-air con-$ centrations the coproporphyrinuria also increased; except in two cases all the workers $(n=39)$ with an exposure to $>0.15 \mathrm{mg}$. $\mathrm{Pb} / \mathrm{m}^{3}$ had a coproporphyrinuria $\geqslant 3$; and finally there was no increase in coproporphyrinuria with increasing duration of exposure.

Table 1 includes only those workers about whom there was a reasonable knowledge of duration and intensity of exposure in the past.

We may disregard the work history and correlate the frequency distribution of coproporphyrinuria in groups of workers of factories $A$ and $B$ with the lead-in-air concentration present at the time of examination. This is done in Fig. 1, in which a group of workers never occupationally exposed to lead has also been included. In the group exposed 
to $<0.05 \mathrm{mg} . \mathrm{Pb} / \mathrm{m}^{3}$ some workers were included who had recently been transferred from departments with higher exposure, and some of them still showed a moderately increased coproporphyrinuria ( $c f$. Table 1). The correlation coefficient for lead-in-air
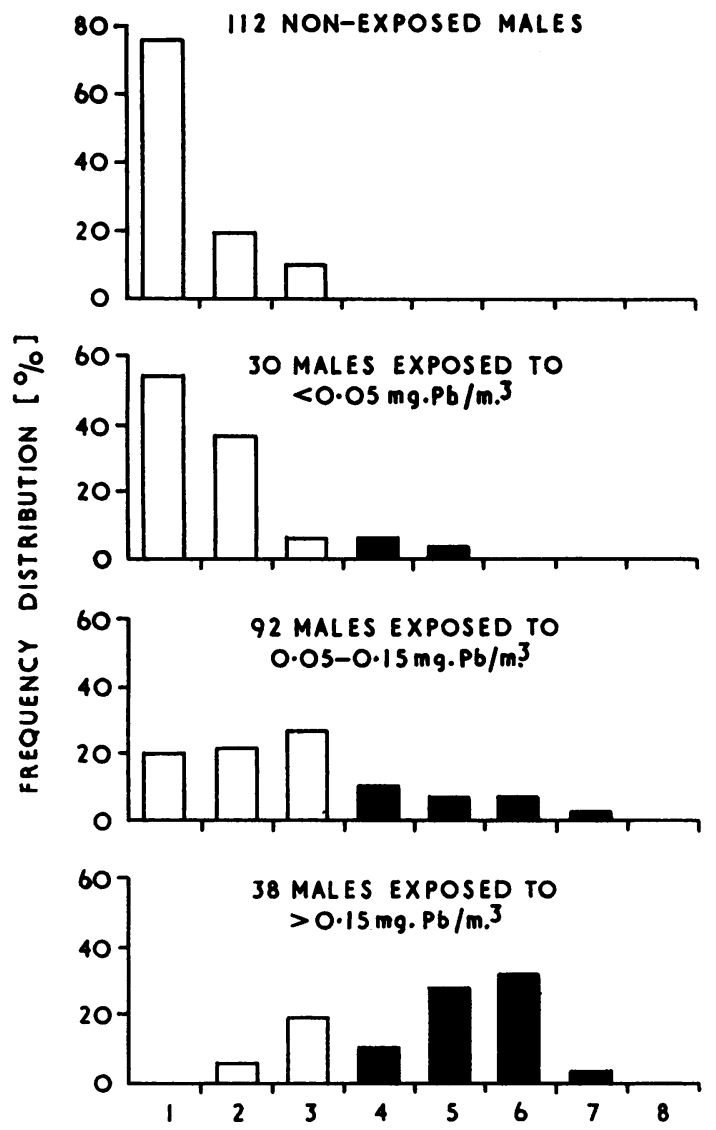

COPROPORPHYRINURIA [DONATH SCALE]

FIG. 1.-Frequency distributions of coproporphyrinuria in relation to lead-in-air concentration. The exposed subjects were all working in two lead pigment factories.

concentrations with individual values of coproporphyrinuria was in factory $\mathrm{A}, 0.478(\mathrm{p}<0.001)$ and in factory $B, 0.510(p<0.001)$. By means of the frequency distributions of coproporphyrinuria it is therefore possible to make a rough estimate of the lead-in-air concentrations in a department. The determination of coproporphyrinuria in a group of workers provides a method of obtaining a first impression of the conditions in a lead processing factory.

Some examples of such frequency distributions in different industries are given in Fig. 2, which also shows the distributions of haemoglobin values. In Fig. 2 a deviation to the right is seen for both coproporphyrinuria and haemoglobin frequency distributions. Haemoglobin was determined with the Siccahaemometer. For 16 groups of workers the average coproporphyrinuria values $\left(\frac{\Sigma \text { coprop. }}{n}\right)$ and the percentage of individuals with haemoglobin $\leqslant 13.7 \mathrm{~g} . / 100 \mathrm{ml}$. were calculated (i.e. those with low haemoglobin values). Each group consisted of more than 20 workers (Table 2 and Fig. 3). The correlation between the percentage with low haemoglobin and raised coproporphyrinuria is high $(r=0.91)$. The frequency distribution of coproporphyrin values therefore gives some indication of the degree of anaemia in the same group of workers.

Because in chronic exposure to lead a decrease in haemoglobin usually precedes the occurrence of subjective symptoms, prevention of anaemia is at the same time prevention of manifest intoxication. In non-exposed workers of the same socio-economic status in factories A and B we found $25 \%$ with haemoglobin $\leqslant 13.7 \mathrm{~g} . / 100 \mathrm{ml}$. An increase in frequency of low haemoglobin values in exposed groups may be regarded as due to lead intake. From Fig. 3 it may be concluded that the normal frequency of $25 \%$ is surpassed if the average coproporphyrinuria exceeds 2 to 2.5 on the Donath scale (e.g. $50-100 \gamma / 1$.). This value, therefore, may be regarded as the maximum allowable coproporphyrinuria in groups of workers. This maximum allowable average coproporphyrinuria of 2 to 2.5 corresponds to a lead-in-air concentration of about $0.1 \mathrm{mg} . \mathrm{Pb} / \mathrm{m}^{3}$ (Zielhuis, 1959b), at least under the conditions which prevail in lead pigment industries in the Netherlands.

A coproporphyrinuria of 8 on the Donath scale has never been found, even in manifest intoxication. This probably does not mean that the coproporphyrinuria did not exceed $3000 / 1$., but that the discrimination between degree 7 and 8 is dubious, because the increase in intensity of fluorescence approaches a horizontal level. A modification of the scale of Donath is therefore suggested: degree 7 may be regarded as coproporphyrinuria $\geqslant 1600 \gamma / 1$.

\section{Discussion}

From the foregoing data some conclusions for the practice of industrial hygiene may be drawn. The frequency distribution of coproporphyrin values in groups of workers gives the following information:

(a) If the average coproporphyrinuria exceeds 1.5 degrees on the Donath scale there is an increased lead intake. 

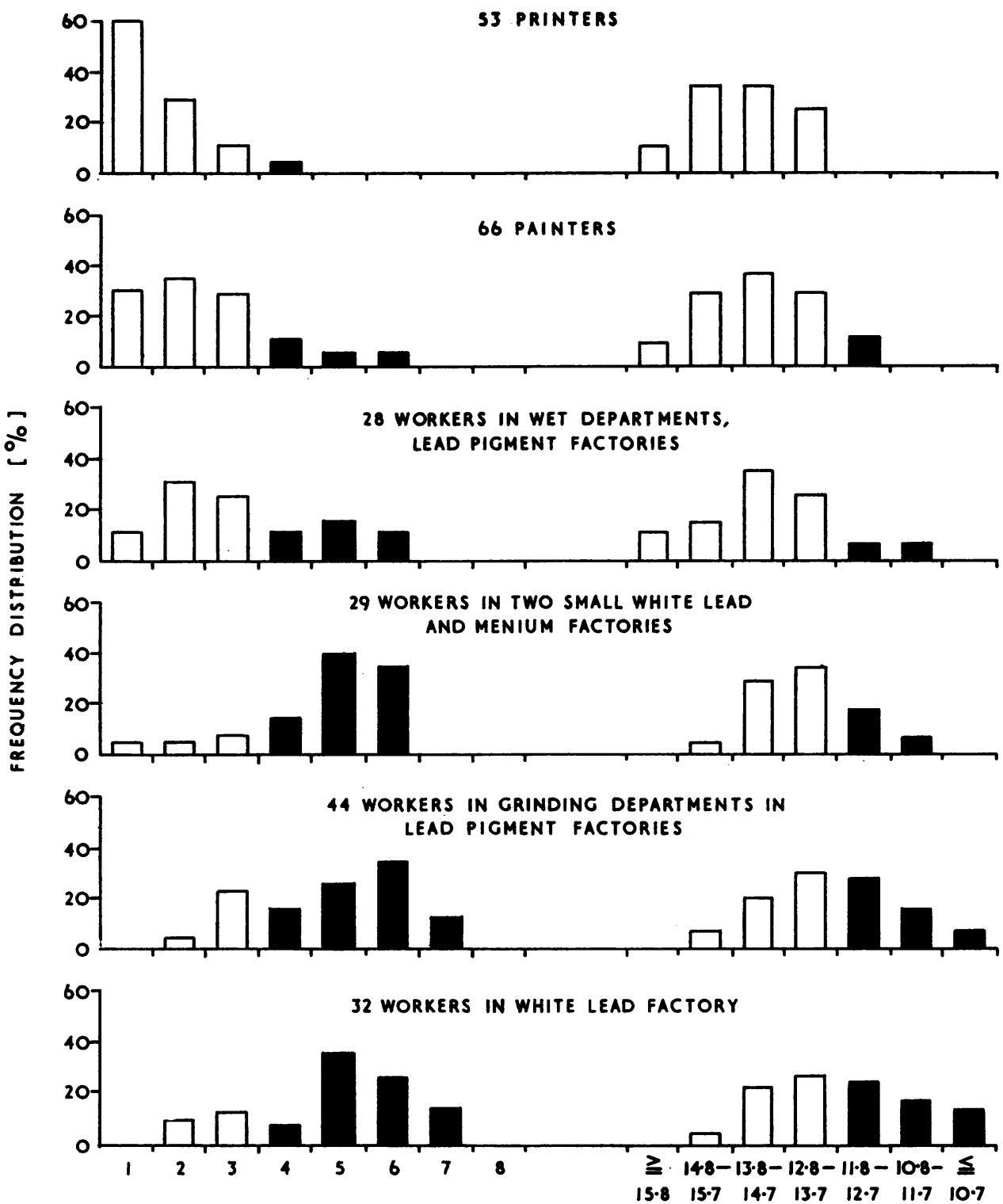

COPROPORPHYRINURIA [DONATH SCALE]

haEmoglosin [ $9 . / 100 \mathrm{ml}$.

FIG. 2.-Frequency distributions of coproporphyrinuria and haemoglobin in different groups of workers.

(b) If the average coproporphyrinuria lies between 1.5 and 2.5 degrees the exposure is within allowable limits.

(c) If the average coproporphyrinuria exceeds $2 \cdot 5$ degrees the maximumallowable concentration for lead in air $\left(0 \cdot 1 \mathrm{mg} . \mathrm{Pb} / \mathrm{m}^{3}\right)$ has probably been surpassed.

(d) From the frequency distribution of copropor- phyrinuria the degree of air pollution with lead and the degree of anaemia due to lead intake may be roughly estimated.

These conclusions are valid for groups of workers numbering 20 or more. Plotting the values on a floor plan of the factory may lead to the discovery of areas of high lead exposure. 
TABLE 2

SIXTEEN GROUPS OF WORKERS: AVERAGE COPROPORPHYRINURIA ESTIMATIONS AND PERCENTAGES OF PERSONS WITH HAEMOGLOBIN OF $13.7 \mathrm{~g} . / 100 \mathrm{ml}$. OR LESS

\begin{tabular}{|c|c|c|c|}
\hline Group & No. of Persons & $\begin{array}{c}\text { Average } \\
\text { Coproporphyrinuria } \\
\text { (Donath Scale) }\end{array}$ & $\begin{array}{c}\% \text { Persons with } \\
\text { Haemoglobin } \leqslant \\
13.7 \mathrm{~g} . / 100 \mathrm{ml} .\end{array}$ \\
\hline $\begin{array}{l}\text { Males not exposed to lead } \\
\text { Printers } \\
\text { Workers exposed to }<0.05 \mathrm{mg} \text {. Pb/m } \mathrm{m}^{3} \text { (Fig. 1) } \\
\text { Production department workers for non-lead-pigments } \\
\text { Maintenance department workers in lead pigment factories } \\
\text { Painters } \\
\text { Ship-yard weiders } \\
\text { Workers exposed to } 0 \cdot 05-0 \cdot 15 \mathrm{mg} . \mathrm{Pb} / \mathrm{m}^{3}{ }^{3} \text { (Fig. 1) } \\
\text { Wet department workers in lead pigment factories } \\
\text { Lead burners and welders } \\
\text { Ship-yard ship cleaning workers } \\
\text { Workers exposed to }>0 \cdot 15 \mathrm{mg} . \mathrm{Pb} / \mathrm{m}^{3} \text { (Fig. 1) }^{\text {1) }} \\
\text { Workers in two small white lead and menium factories } \\
\text { White lead factory workers } \\
\text { Grinding department workers in lead pigment factories } \\
\text { Workers in small accumulator factories }\end{array}$ & $\begin{array}{r}112 \\
53 \\
30 \\
27 \\
61 \\
66 \\
44 \\
92 \\
28 \\
36 \\
37 \\
38 \\
29 \\
32 \\
44 \\
21\end{array}$ & $\begin{array}{l}1 \cdot 4 \\
1 \cdot 5 \\
1 \cdot 8 \\
2 \cdot 1 \\
2 \cdot 3 \\
2 \cdot 4 \\
2 \cdot 7 \\
3 \cdot 0 \\
3 \cdot 2 \\
4 \cdot 4 \\
4 \cdot 5 \\
4 \cdot 7 \\
4 \cdot 8 \\
4 \cdot 9 \\
4 \cdot 9 \\
5 \cdot 0\end{array}$ & $\begin{array}{r}4 \\
23 \\
33 \\
33 \\
24 \\
33 \\
46 \\
32 \\
39 \\
47 \\
89 \\
74 \\
69 \\
75 \\
76 \\
62\end{array}$ \\
\hline
\end{tabular}

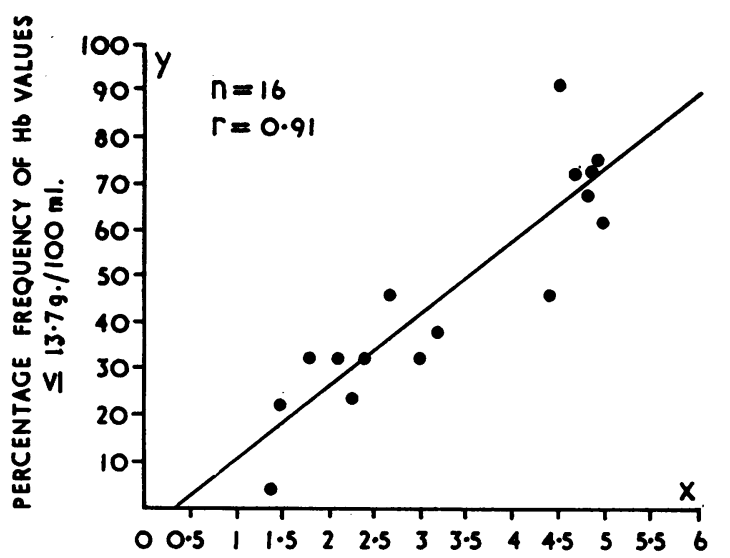

AVERAGE COPROPORPHYRINURIA VALUES [DONATH SCALE]

Fig. 3.-Correlation between low haemoglobin values and coproporphyrinuria in 16 groups of workers. $y=6 \cdot 5+16 \cdot 1 x$.

If the coproporphyrinuria values of the group are generally within normal limits or are only slightly increased, no danger of manifest lead intoxication exists, and determination of the number of basophil punctated erythrocytes or haemoglobin is not necessary because disturbance of function (i.e. anaemia) is not likely to take place. If the coproporphyrinuria values, however, exceed the allowable range, individual counting of basophils and haemoglobin is necessary. In that case, the individual values for coproporphyrinuria cannot be the only criteria, as in an individual the degree of coproporphyrinuria does not indicate sufficiently accurately the extent of lead absorption, except in a negative sense: normal coproporphyrin excretion generally indicates absence of increased lead absorption.

\section{REFERENCES}

Donath, W. F. (1955). T. soc. Geneesk., 33, 91.

(1956). Arh. Hig. Rada, 7, 77.

latt, M. W., and Goldblatt, J. (1956). In Industrial Medicine and Hygiene, ed. E. R. A. Merewether, vol. 3, p. 185. Butterworth, London.

Gupta, M. N., and Iyer, C. R. H. (1954). Proc. Soc. industr. Med., (Jamshedpur), 6, 176.

Harrold, G. C., Meek, S. F., and Padden, D. A. (1952). A.M.A Arch. industr. Hyg., 6, 24.

Hijmans van den Bergh, A. A., and Grotepass, W. (1933). Klin. Wschr., 12, 586.

Johnson, W. S., and Whitman, N. E. (1950). Ibid., 2, 170

Pinto, S. S.. Einert, C., Roberts, W. J., Winn, G. S., and Nelson, S. W. Einert, (1952). Ibid., 6, 496 .

Vannotti, A. (1937). Arch. Gewerbepath. Gewerbehyg., 8, 240.

Waldman, R. K., and Seideman, R. M. (1950). A.M.A. Arch. industr. Hyg., 1, 290.

Wyllie, J. (1955). A.M.A. Arch. industr. Hlth, 12, 396.

Zielhuis, R. L. (1959a). Verhandeling Ned. Instit. praev. Geneesk, 